○荒木 進 ${ }^{1.2)}$ 、飯塚尚久 ${ }^{1)}$ 、佐藤恒正 ${ }^{2)}$ 、北村剛一 ${ }^{1)}$ 、山根雅昭 ${ }^{1)}$ 、鈴木 衞 $^{22}$ ( 東京慜察病院耳鼻科 ${ }^{1)}$ 、東京医科大学耳鼻科 ${ }^{2)}$ )

【はじめに】突発性難聴に対する高気压酸素療法の有効性は以前より多数の報告 1) 2) 8) 4) があるが、実施できる施設が限られており、また、渗出性中耳炎の併発や治療中の压迫感 などで、治療を中断せざるをえない例が存在するのが現状である。この結果、一部の施設 を除いて、ステロイド点滴静注療法を施行されたが無効であった陳旧例などに高気圧酸素 療法が選択されるととも多い。突発性難聴の原因にかかわらず、内耳の病態として、循環 障害と代謝障害からくる酸素不足が生じていると考えられる。また、それが早期に改善さ れるととが内耳組織の不可逆的な損傷を防止すると思われる。治癒過程に酸素が重要であ れば、酸素を吸入させるだけでも何らかの効果が期待できるはずであり、その効果は $5 \%$ $\mathrm{CO}_{2}-95 \% \mathrm{O}_{2}$ ガス吸入療法として 1978 年に村田 ${ }^{5)}$ により報告されている。しかし、その 後の酸素吸入療法の報告は少なく、十分な追試が必要であると考えられる。今回、純酸素 を経鼻的に投与し、その有効性について検討したので報告する。

【対象と方法】1998年 7 月から1999年 6 月までに入院し点滴加療と同時に経鼻的酸素吸 入を施行した、突発性難聴患者 18例を対象とし、1997年 4 月から1998年 9 月までの期間に 入院加療したが酸素吸入療法を加えなかった26例と比較検討した。両側型、低音障害型や 再発変動をくりかえす例や、内リンパ水腫確診例を除いた、純音聴力検查における5分 法による平均聴力レベルが $40 \mathrm{~dB}$ 以上で、健耳の平均聴力レベルが $40 \mathrm{~dB}$ 未満の 20 歳以上 の症例を今回の対象の条件とした。点滴療法はステロイド、ビタミン $\mathrm{B}_{1} 、 \mathrm{~B}_{12}$ 製剤、ATP 製剂、低分子デキストランを基本とし、症例によってはプロスタグランディン $\mathrm{E}_{1}$ 製剤やウ ロキナーゼの点滴投与、未梢血管拡張薬の内服などを追加した。酸素は 4 リットル(不快 感を示した場合は 2 リットル)の純酸素とし、点滴を施行している約 5 時間（最短 2 時間、 最長 7 時間)、経舅的に連日継続投与した。初診時と退院時の平均聴力レベルょり、拜生 省突発性難聴研究班の判定基準に基づた治療成績の判定を行い、治癒、著明回復を改善 とし、回復までを有効として 2 群間の有意差検定を行った。

【結果】酸素吸入療法を施行した18例を表 1 に示した。不変または悪化症例はなかったが、 著明回復に到らなかった 5 例中 4 例は $90 \mathrm{~dB}$ 以上の高度難聴例であった。改善率は $72.2 \%$ 、 有効率は $100 \%$ であった。一方、以前の酸素吸入を加えなかった群の改善率は $42.3 \%$ 、有 効率は $76.9 \%$ となり、 $\chi^{2}$ 検定により両群間に有意差を認めた。（改善率： $x^{2}=3.84$ 、 $\mathrm{p}=0.05$ 、有効率 : $x^{2}=4.81 、 \mathrm{p}=0.03$ )（表 $2 ）$

【まとめ】経鼻的酸素吸入療法は、入院中であれば、比較的簡便で患者への負担の少ない 治療法である。従来の治療法に加えることにより、治療効果の上昇が期待できるのではな いかと考えられた。

\title{
【参考文献 】
}

1）三宅 弘、柳田則之：突発性難聴の高気圧酸素療法。耳鼻臨床 $70: 8 ； 791 \sim 794$, 1977 . 
2）都築 達、藤岡 正：突発性難聴に対する高圧酸素療法の検討.耳鼻臨床 81：11； 1581 1586, 1988.

3）牧嶋和見：突発性難聴の病理病態と治療の接点. 日高圧医誌 $23: 2 ; 57 \sim 63,1988$.

4）村橋けい子：乫発性難聴に対する高気圧酸素療法。一その治療効果と限界一 日高王 医誌 23\%：2；77～82, 1988.

5）村田清高：突発性難聴、5\% $\mathrm{CO}_{2}-95 \% \mathrm{O}_{2}$ ガス吸入療法。耳鼻臨床 $71: 1151$ 1159, 1978.

表 1

\begin{tabular}{|c|c|c|c|c|c|c|c|}
\hline & 年齢 & 性別 & 聴力型分類 & 治療開始 & 初診時聴力 & 院時聴力 & 効果判定 \\
\hline 1 & 45 & 男 & 高音漸傾型 & 第13病日 & $83 \mathrm{~dB}$ & $31 \mathrm{~dB}$ & 著明回復 \\
\hline 2 & 24 & 男 & 水平型 & 第8病日 & $74 \mathrm{~dB}$ & $10 \mathrm{~dB}$ & 治癒 \\
\hline 3 & 59 & 男 & 水平型 & 第7病日 & $86 \mathrm{~dB}$ & $32 \mathrm{~dB}$ & 著明回復 \\
\hline 4 & 69 & 女 & 水平型 & 第3病日 & $87 \mathrm{~dB}$ & $32 \mathrm{~dB}$ & 著明回復 \\
\hline 5 & 80 & 女 & 水平型 & 第8病日 & $68 \mathrm{~dB}$ & $32 \mathrm{~dB}$ & 著明回復 \\
\hline 6 & 60 & 女 & 水平型 & 第12病日 & $84 \mathrm{~dB}$ & $53 \mathrm{~dB}$ & 著明回復 \\
\hline 7 & 56 & 女 & 水平型 & 第9病日 & $77 \mathrm{~dB}$ & $14 \mathrm{~dB}$ & 治癒 \\
\hline 8 & 42 & 男 & 高音漸傾型 & 第6病日 & $92 \mathrm{~dB}$ & $70 \mathrm{~dB}$ & 回復 \\
\hline 9 & 50 & 男 & 谷型 & 第7病日 & $61 \mathrm{~dB}$ & $14 \mathrm{~dB}$ & 治癒 \\
\hline 10 & 50 & 男 & 水平型 & 第5病日 & $74 \mathrm{~dB}$ & $19 \mathrm{~dB}$ & 治癒 \\
\hline 11 & 53 & 男 & scale out型 & 第2病日 & $97 \mathrm{~dB}$ & $68 \mathrm{~dB}$ & 回復 \\
\hline 12 & 27 & 女 & 水平型 & 第7病日 & $68 \mathrm{~dB}$ & $11 \mathrm{~dB}$ & 治癒 \\
\hline 13 & 53 & 男 & 水平型 & 第5病日 & $83 \mathrm{~dB}$ & $18 \mathrm{~dB}$ & 治癒 \\
\hline 14 & 54 & 男 & 水平型 & 第2病日 & $68 \mathrm{~dB}$ & $9 \mathrm{~dB}$ & 治癒 \\
\hline 15 & 41 & 男 & scale out型 & 第6病日 & $108 \mathrm{~dB}$ & $57 \mathrm{~dB}$ & 著明回復 \\
\hline 16 & 64 & 男 & 水平型 & 第8病日 & $65 \mathrm{~dB}$ & $52 \mathrm{~dB}$ & 回復 \\
\hline 17 & 24 & 男 & scale out型 & 第5病日 & $111 \mathrm{~dB}$ & $92 \mathrm{~dB}$ & 回復 \\
\hline 18 & 39 & 女 & 高音漸傾型 & 第2病目 & $97 \mathrm{~dB}$ & $85 \mathrm{~dB}$ & 回復 \\
\hline
\end{tabular}

表2

\begin{tabular}{l|c|c|c|c|c}
\hline 酸素吸入 & $\mathrm{No}_{0}$ & 治癒 & 著明回復 & 回復 & 不変 \\
\hline あり & 18 & 7 & 6 & 5 & 0 \\
\hline なし & 26 & 5 & 6 & 9 & 6 \\
\hline
\end{tabular}

